\title{
POLITIK HUKUM RATIFIKASI KONVENSI PBB ANTI KORUPSI DI INDONESIA*
}

\author{
Atep Abdurofiq \\ Fakultas Syariah dan Hukum UIN Jakarta \\ Jl. Ir. H. Juanda No. 95 Ciputat Tangerang Selatan \\ E-mail: atep.abdurofiq@uinjkt.ac.id \\ DOI: $10.15408 /$ jch.v4i2.4099
}

\begin{abstract}
Abstact: This study sought to see an international legal ratification of UN conventions in the form of anti-corruption and its impact on the internal environment of a country, especially Indonesia.Corruption is a never-ending problem discussed and resolved. Corruption became the nation's disease because it has been longstanding, massive and systemic. Corruptions become a disaster for the national economy and undermine system of governance. Corruption is not merely the loss of state money, but the impact on poverty and the miserable life of the people. Indonesia considers the UN anti-corruption convention is quite important in the effort to uphold the "good governance" and create a climate conducive to investment. International cooperation is needed to resolve the problem of corruption in order to prevent and eradicate corruption, of course, need to be supported by integrity, accountability, and management of good governance and the nation Indonesia has been active in the international community's efforts to prevent and eradicate corruption to have signed the United Nations Convention against Corruption, 2003 (United Nations Convention Against Corruption, 2003). Ratification is an attempt to construct the identity of Indonesia that first acts as a corrupt country into a country that has a desire to create a clean government.
\end{abstract}

Keywords : Ratification, UN Convention on Fighting Corruption, Indonesia

\begin{abstract}
Abstrak: Tulisan ini mencoba untuk melihat ratifikasi hukum internasional khususnya konvensi PBB anti korupsi serta dampaknya bagi kondisi dalam negeri sebuah Negara, khususnya Indonesia. Indonesia memandang konvensi PBB anti korupsi cukup penting dalam upaya menegakkan "good governance" dan menciptakan iklim investasi yang kondusif. Kerjasama internasional diperlukan untuk menyelesaikan masalah korupsi ini dalam rangka pencegahan dan pemberantasan tindak korupsi, tentunya perlu didukung oleh integritas, akuntabilitas, dan manajemen pemerintahan yang baik. Indonesia telah ikut aktif dalam upaya masyarakat internasional untuk pencegahan dan pemberantasan korupsi dengan menandatangani Konvensi Perserikatan Bangsa-Bangsa Anti Korupsi, 2003. Ratifikasi merupakan upaya konstruksi identitas Indonesia sebagai negara yang korup menjadi negara yang mempunyai keinginan untuk menciptakan pemerintahan yang bersih.
\end{abstract}

Kata Kunci : Ratifikasi, Konvensi PBB Anti Korupsi, Indonesia.

* Naskah diterima: 22 April 2016, direvisi: 23 Mei 2016, disetujui untuk terbit: 25 September 2016. 


\section{Atep Abdurofiq}

\section{Pendahuluan}

Beberapa waktu yang lalu kita mendengar seorang ketua lembaga tinggi negara tersangkut kasus suap kuota gula dan sedang hangat-hangatnya dibicarakan publik, terutama dalam media massa baik lokal maupun nasional. Pada hakekatnya, korupsi adalah "patologi sosial" yang merusak struktur pemerintahan, dan menjadi penghambat utama terhadap jalannya pemerintahan dan pembangunan pada umumnya. Dalam praktiknya, korupsi sangat sukar bahkan hampir tidak mungkin dapat diberantas, oleh karena sangat sulit memberikan pembuktian-pembuktian yang akurat. Di samping itu sangat sulit mendeteksinya dengan dasar-dasar hukum yang pasti. Namun akses perbuatan korupsi merupakan bahaya laten yang harus diwaspadai baik oleh pemerintah maupun oleh masyarakat itu sendiri.

Korupsi adalah produk dari sikap hidup satu kelompok masyarakat yang memakai uang sebagai standar kebenaran dan sebagai kekuasaaan mutlak. Sebagai akibatnya, kaum koruptor yang kaya raya dan para politisi korup yang berkelebihan uang bisa masuk ke dalam golongan elit yang berkuasa dan sangat dihormati. Mereka ini juga akan menduduki status sosial yang tinggi di mata masyarakat. Korupsi sudah berlangsung lama, sejak zaman Mesir Kuno, Babilonia, Roma sampai abad pertengahan dan sampai sekarang. Korupsi terjadi di berbagai negara, tak terkecuali di negara-negara maju sekalipun. Di negara Amerika Serikat sendiri yang sudah begitu maju masih ada praktik-praktik korupsi. Sebaliknya, pada masyarakat yang primitif di mana ikatan-ikatan sosial masih sangat kuat dan kontrol sosial yang efektif, korupsi relatif jarang terjadi.

Tetapi dengan semakin berkembangnya sektor ekonomi dan politik serta semakin majunya usaha-usaha pembangunan dengan pembukaanpembukaan sumber alam yang baru, maka semakin kuat dorongan individu terutama di kalangan pegawai negeri untuk melakukan praktik korupsi dan usaha-usaha penggelapan. Korupsi dimulai dengan semakin mendesaknya usaha-usaha pembangunan yang diinginkan, sedangkan proses birokrasi relatif lambat, sehingga setiap orang atau badan menginginkan jalan pintas yang cepat dengan memberikan imbalan-imbalan dengan cara memberikan uang pelicin (uang sogok).

Praktik ini akan berlangsung terus menerus sepanjang tidak adanya kontrol dari pemerintah dan masyarakat, sehingga timbul golongan pegawai yang termasuk OKB-OKB (orang kaya baru) yang memperkaya diri sendiri (ambisi material). Agar tercapai tujuan pembangunan nasional, maka mau 
tidak mau korupsi harus diberantas. Ada beberapa cara penanggulangan korupsi, dimulai yang sifatnya preventif maupun yang represif. Korupsi merupakan suatu penyakit ganas yang menggerogoti kesehatan masyarakat seperti penyakit kanker yang setapak demi setapak menghabisi daya hidup manusia.

Pendapat ini dikemukakan ahli sosiologi terkemuka Selo Sumardjan dalam pengantarnya untuk buku 'Membasmi Korupsi' karya Robert Klitgaard (1988). Pandangan Selo ini secara tegas membantah pendapat sebagian orang yang mengatakan bahwa korupsi merupakan bagian dari sisi gelap mental bangsa Indonesia. Pendapat yang sekilas terasa benar ini muncul mengingat begitu meluasnya praktik-praktik korupsi di berbagai sektor serta kelompok masyarakat di Indonesia. Lebih dari itu, dengan semakin intensifnya upaya untuk mendorong demokratisasi dan transparansi dalam berbagai lapangan kehidupan, makin banyak pula pemerintahan di negara-negara di dunia ini yang melakukan langkah-langkah setahap demi setahap untuk mengupayakan terciptanya penyelenggaraan negara yang bersih dan bebas dari korupsi.

Jika kita melihat dengan seksama, apabila persoalan tentang korupsi ini tidak diperhatikan secara serius oleh suatu negara atau rezim dari suatu negara, hal itu akan menjadikan segala struktur di dalam rezim atau negara tersebut menjadi para "penghisap darah" yang menggerogoti habis segala sendi-sendi dalam negara dan pada akhirnya mengurangi efisiensi perekonomian, meruntuhkan legitimasi politis dan rasa keadilan masyarakat.

Dalam konteks nasional persoalan pemberantasan korupsi sangat penting dalam kehidupan politik dan hukum, terutama erat kaitannya dengan upaya pemerintah sebagai penyelenggara negara dalam mengurangi atau bahkan menghilangkan praktik-prektik korupsi. Besar atau tidaknya suatu negara mempunyai "political will" dan komitmen untuk melakukan pemberantasan korupsi minimal diukur dari banyaknya regulasi tentang korupsi yang telah diratifikasi dan diimplementasikan oleh suatu negara.

Implementasi konvensi tentang anti korupsi ini penting, mengingat pertama, untuk mengatasi dan mengakhiri praktik-praktik korupsi yang dilakukan oleh pejabat publik (aparat negara). Kedua, untuk menggalang kerjasama yang bersifat multilateral dalam mencegah dan mengatasi dan mengakhiri praktik-praktik korupsi baik langsung maupun tidak langsung yang melibatkan pejabat publik (aparat negara). Namun demikian, implementasi konvensi internasional dalam suatu negara tidak serta merta, namun melalui prosedur yang dinamakan dengan ratifikasi. 


\section{Atep Abdurofiq}

Dalam kaitan tanggung jawab pemerintah untuk memerangi praktikpraktik korupsi dengan ratifikasi konvensi tentang anti korupsi, maka terkait pula dengan kewenangan pemerintah sebagai pihak yang mempunyai political will untuk merumuskan kebijakan hukum (legal policy) tentang anti korupsi. Dengan kata lain, dalam rangka memerangi korupsi tersebut pemerintah diharuskan mempunyai politik hukum. Seperti disampaikan oleh Reus Smit, Politik hukum internasional mempunyai 2 makna yaitu:

a. Menjelaskan bagaimana politik mempengaruhi, membentuk dan mengarahkan hukum internasional. Hukum internasional merupakan refleksi dari politik kekuasaan atau sebagai solusi fungsional untuk menyelesaikan persoalan.

b. Menjelaskan politik dalam hukum internasional; bahwa hukum bisa membentuk politik, politik bisa mengambil bentuk yang berbeda ketika berada dlm praktek hukum dan legal reasoning.

Tujuan dari Reus-Smit adalah untuk memberikan pemahaman yang lebih baik mengenai dua makna tersebut. Bagaimana politik internasional mempengaruhi hukum internasional dan sebaliknya bagaimana hukum merupakan feedback atau sebuah masukan yang membentuk suatu (ekspresi/tindakan) politik. ${ }^{1}$ Dari uraian yang disampaikan oleh Reus Smit di atas maka politik hukum ratifikasi konvensi anti korupsi diartikan sebagai keputusan politik tentang ratifikasi konvensi anti korupsi yang mencakup kebijakan negara tentang bagaimana ratifikasi konvensi tersebut dibuat dan dan dilaksanakan untuk membangun masa depan yang lebih baik, yakni kehidupan negara yang bersih dari praktek-praktek korupsi terutama yang dilakukan oleh pejabat publik.

Korupsi seperti tak pernah habis dibicarakan dan terselesaikan. Korupsi menjadi penyakit bangsa ini karena telah berlangsung lama, massif dan sistemik. Korupsi menjadi bencana bagi perekonomian nasional dan merusak sistem penyelenggaraan pemerintahan. Korupsi tidak hanya sematamata hilangnya uang negara, akan tetapi berdampak pada kemiskinan dan menyengsarakan kehidupan rakyat. Peraturan perundang-undangan telah mencapnya sebagai kejahatan luar biasa (extra ordinary crime).

Korupsi telah menjarah uang negara dari berbagai sektor, dari sektor perbankan, BUMN, instansi/departemen pemerintahan hingga kekayaan alam

${ }^{1}$ Christian Reus Smit, The Politics of International Law (Cambridge: Cambridge University Press, 2004), h. 14. 
yang semestinya bisa digunakan untuk kemakmuran rakyat. Pelakunya pun bukan pejabat biasa, mulai dari presiden hingga pejabat di pemerintahan pusat dan daerah (legeslatif dan eksekutif). Jika dilihat dari uang negara yang telah dikorupsi, jumlahnya sangat besar. Mantan Menteri Keuangan dan Kepala Bappenas, Kwik Kian Gie (2003), pernah mengkalkulasi uang negara yang dikorup dari perpajakan dan belanja APBN tahun 2003 sebesar 215 trilyun. $^{2}$ Jaksa Agung, Abdurrahman Saleh, di dalam sambutan Dies Natalis Univ. Pekalongan ke-23 mengungkapkan, uang negara yang dikorupsi jumlahnya sangat besar, yakni mencapai Rp 305 triliun. Angka itu belum termasuk korupsi yang terjadi di lingkungan pengadilan ataupun kejaksaan yang sangat sulit ditemukan karena tidak tampak. ${ }^{3}$

Sedangkan dari data yang dikumpulkan oleh Kompas, ICW serta BPK sampai dengan tahun 2014, jumlah uang negara yang dikorup mencapai 534, 3 Triliun, seperti terangkum dalam infografis berikut ini:

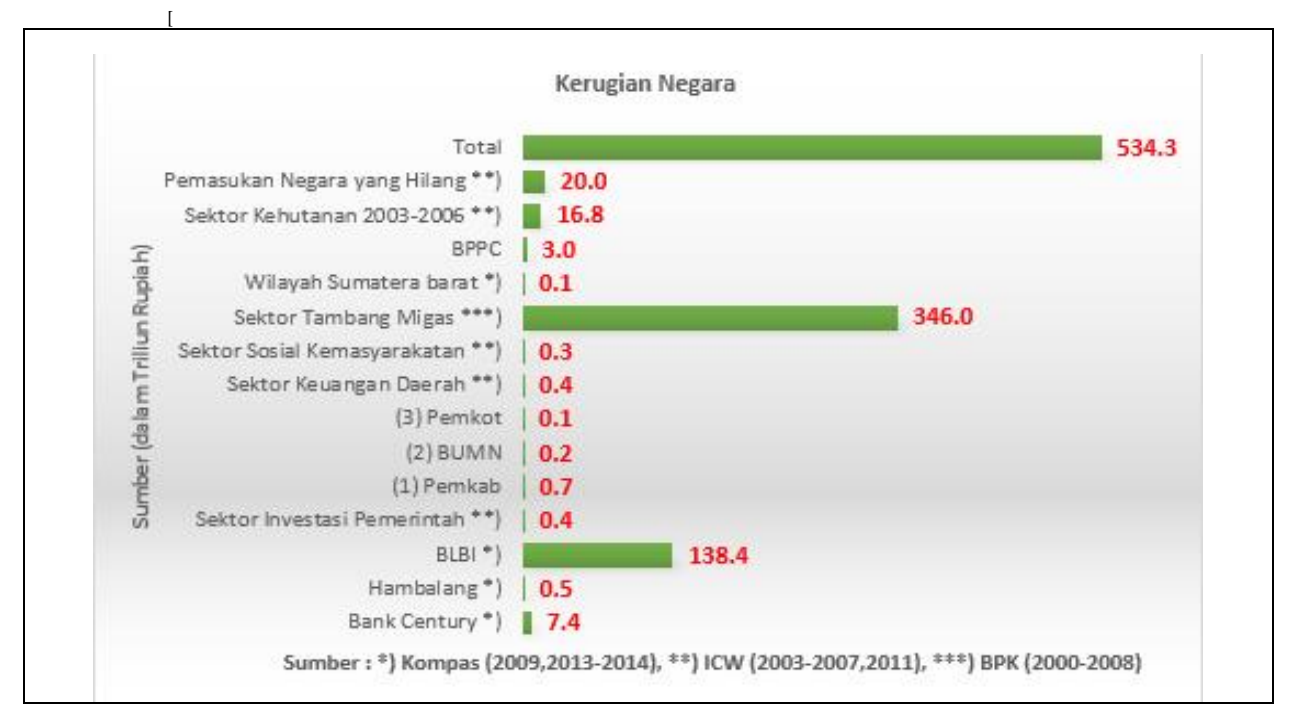

\section{Ratifikasi}

Suatu perjanjian internasional itu, bila ditinjau dari segi pembuatannya, dapat dibagi dalam tiga tahap, yaitu pertama, perundingan (negotiation),

2 Kwik Kian Gie, Pemberantasan Korupsi Untuk Meraih Kemandirian, Kesejahteraan, Kemakmuran dan Keadilan, 2003, hlm. 13.

${ }^{3}$ Suara Merdeka 06/09/05http://www.bakun.go.id/modul/terkini/index.php?id=1379, 18 September 2016. 


\section{Atep Abdurofiq}

penandatanganan (signature) dan pengesahan (ratification). Dua, apabila didasarkan pada tahap-tahap pembuatannya itu, perjanjian internasional dapat dibedakan dalam dua jenis, pertama, perjanjian yang diadakan melalui tiga tahap pembuatan, yaitu: perundingan, penandatanganan dan pengesahan; kedua, perjanjian internasional yang pembuatannya hanya melalui dua tahap saja, yaitu: perundingan dan penandatanganan. Jadi, suatu perjanjian internasional, untuk dapat mengikat suatu negara, ada kalanya ditetapkan dengan melalui suatu pengesahan atau ratifikasi. Tentang ratifikasi ini dianggap sebagai hal yang penting untuk mengikat diri pada suatu perjanjian. Jadi kini ratikasi itu telah menjadi suatu elemen yang pokok untuk mengikat diri pada suatu perjaniian antar negara.

Pengertian dari ratifikasi itu sendiri dikemukakan oleh beberapa ahli hukum, di antaranya adalah Mochtar Kusumaatmadja menyatakan bahwa ratifikasi adalah pengesahan atau penguatan oleh badan yang berwenang di negaranya terhadap suatu perjanjian. Menurut Wirjono Prodjodikoro, ratifikasi adalah suatu pernyataan resmi dari pemerintah negara masing-masing yang mengesahkan treaty. Starke mengatakan, ratifikasi adalah persetujuan dari kepala negara atau pemerintah atas tanda tangan wakilnya yang terdapat pada traktat. Menurut Ian Brownlie, ratifikasi merupakan salah satu bentuk pernyataan negara tentang kesediaannya untuk diikat oleh suatu perjanjian internasional. Indonesia sebagai negara berdaulat dan anggota masyarakat internasional, sudah barang tentu mempunyai cara atau sistem dan prosedur tertentu untuk meratifikasi perjanjian internasional.

Di dalam Undang-Undang Dasar yang berlaku saat sekarang, yaitu UUD 1945, terdapat Pasal 11 sebagai dasar hukum untuk ratifikasi. Tetapi Pasal 11 UUD 1945 ini tidak memuat secara jelas tentang masalah ratifikasi, baik tentang pembagian perjanjian yang penting dan tidak penting, maupun tentang bagaimana bentuk persetujuan dari DPR. Pasal 11 UUD 1945 itu, bunyi lengkapnya adalah sebagai berikut: "Presiden dengan persetujuan Dewan Perwakilan Rakyat, menyatakan perang, membuat perdamaian dan perjanjian dengan negara lain."4

\section{Reason for Action dalam Konstruktivisme}

Gagasan utama konstruktivisme adalah: pertama, struktur merupakan pembentuk perilaku aktor sosial dan politik. Individu atau negara tidak hanya

4 Mochtar Kusumaatmadja, Pengantar Hukum Internasional, Buku I Bagian Umum, (Bandung: Bina Cipta, 1981), h. 109. 
memiliki aspek material, akan tetapi ada aspek normatif dan ideasional. Kepentingan inilah yang dikembangkan oleh aktor-aktor politik tersebut. Kedua, antara struktur dan agen terdapat hubungan untuk menentukan satu dengan yang lain. Terdapat hubungan yang resiprokal antara aktor dengan struktur di mana struktur dipengaruhi oleh aktor, dan sebaliknya. Ketiga, kepentingan merupakan wujud dari identitas aktor politik. ${ }^{5}$

Munculnya konstruktivisme memberikan konstribusi beberapa penting dalam dunia hubungan internasional, yakni: pertama, bertambahnya materi cara pandang dalam menganalisa suatu fenomena dalam hubungan internasional kaitannya dengan teori perspektif. Sehingga fenomena di dunia internasional dapat dianalisa dari berbagai sudut pandang. Kedua, munculnya konstruktivisme juga sebagai pencetus sebuah pembaharuan kepentingan dalam teori internasional. Ketiga, konstruktivisme membawa sebuah level konseptual dan pengalaman baru dalam menganalisa internasional dan masyarakat dunia.

Dalam buku Reus Smit The Politics of International Law, politik hukum internasional mempunyai 2 makna yaitu: (a) menjelaskan bagaimana politik mempengaruhi, membentuk dan mengarahkan hukum internasional. Hukum internasional merupakan refleksi dari politik kekuasaan atau sebagai solusi fungsional untuk menyelesaikan persoalan, dan (b) menjelaskan politik dalam hukum internasional; bahwa hukum bisa membentuk politik, politik bisa mengambil bentuk yang berbeda ketika berada dalam praktek hukum dan legal reasoning. ${ }^{6}$

Ide bahwa politik berkaitan dengan power dan usaha untuk memaksimalkan tujuan dan bahwa hukum internasional merupakan epiphenomenal dan sebagai a set of functional rules, telah mengalami tantangan selama beberapa dekade terakhir oleh adanya teori internasional konstruktivis. ${ }^{7}$ Sering mendapatkan label sebagai "the new idealists", konstruktivis mengemukakan tiga proposisi utama mengenai the social nature of international relations.

5 Reus-Smith, Christian.Constructivism dalam Scot Burchill, Richard Devetak, (et all). Theories of International Relations, Second Edition. (New York: Palgrave, 2001), h. 209.

${ }^{6}$ Reus Smit, Christian.The Politics of International Law (Cambridge: Cambridge University Press, 2004), h. 14.

7 Adler, Emanuel, "Seizing the middle ground : "Constuctivism in World Politics", European Jurnal of International Relation 3:3 (1997). 


\section{Atep Abdurofiq}

Pertama, struktur sebagai pembentuk perilaku aktor sosial dan politik, baik individual maupun negara, tidak hanya memiliki aspek material, tetapi juga normatif dan ideasional. Respon aktor terhadap lingkungan materialnya tidak hanya dipengaruhi oleh pengetahuan yang ada dalam struktur tertentu tetapi juga dipengaruhi oleh keyakinan intersubyektif yang membentuk identitas aktor dan juga menentukan kepentingannya. ${ }^{8}$

Kedua, konstruktivis membuktikan bahwa jika ingin memahami perilaku negara dan aktor lainnya, maka harus memahami bagaimana identitas sosial mereka mengkondisikan tujuan dan tindakan mereka. Berbeda dengan rasionalis dan realis yang secara tegas mengumpulkan proses-proses pembentukan kepentingan, konstruktivis percaya bahwa identitas sosial aktor mempunyai pengaruh pada kepentingan aktor, dengan implikasi yang signifikan pada bagaimana aktor tersebut berperilaku. ${ }^{9}$

Selanjutnya, identitas harus dilihat secara sosial karena identitas tidak begitu saja terbentuk tetapi dengan melalui pembelajaran dan dialog yang dilakukan aktor dengan norma-norma yang berlaku dari agen atau institusi yang sah yang membentuk peran identitas untuk mendefiniskan sense aktor tersebut. Dalam perspektif ini aktor tidak hanya bertindak untuk merespon lingkungan material mereka; tapi aktor juga memiliki keyakinan-keyakinan intersubyektif, yang kemudian membentuk identitas aktor dan pada gilirannya membentuk kepentingan mereka. Jika ingin memahami perilaku aktor, perlu memahami identitas sosial mereka, di mana identitas itulah yang mengondisikan dan membentuk kepentingan dan tindakan aktor tersebut. Manusia selalu berinteraksi, interaksinya ini akan membentuk keyakinannya dan keyakinan tersebut akan membentuk identitas, identitas kemudian mempengaruhi kepentingan dan kepentingan akan mempengaruhi tindakannya. Karena manusia selalu berinteraksi maka ia bukanlah makhluk yang statis, tapi dinamis, sehingga bisa melakukan perubahan (transformasi). ${ }^{10}$ Inti dari gagasan konstruktivisme adalah reason for action. ${ }^{11}$ Reason merupakan motif individual atau kolektif (alasan mengapa NATO membom Serbia) dan

8 Wendt, Alexander. Social Theory of International Politics (Cambridge: Cambridge University Press, 1999), h. 92-138

${ }_{9}$ Klotz, Audie. Norms in International Relations: The Struggle Against Apartheid (Ithaca: Cornell University Press, 1995), h. 49

10 Wendt, Alexander. The Agent Structure Problem in International Relations Theory, International Organization 41:2, Summer 1987, h. 26-27.

${ }^{11}$ Kratochwil, Friedrich V. Rules, Norms, and Decisions: On the Condition of Practical and Legal Reasoning in International Relations and Domestic Affairs (Cambridge: Cambridge University Press, 1989), h.3 
merupakan justificatory claim. ${ }^{12}$ Reason mempunyai dua dimensi, yaitu dimensi internal dan eksternal atau private-public. Struktur normatif dan ideational membentuk reason aktor dalam dua dimensi yaitu: (a) melalui proses sosialisasi, dengan sosialisasi struktur tersebut membentuk definisi aktor mengenai siapa dia dan apa yang dia inginkan. (b) melalui proses justifikasi publik, dengan justifikasi tersebut struktur tadi memberi kerangka bagi logic of argument.

Konstruktivis memperhatikan tentang pemahaman reason for action, fokusnya tidak hanya pada apa yang disebut dengan logic of appropriateness (logika kepatutan) pada kesesuaian action dengan aturan normatif, tetapi juga pada logic of argumentation (logika argumentasi) dalam hal norma-norma menyediakan kerangka komunikatif di mana aktor-aktor memperdebatkan isuisu agensi yang legitimate, tujuan dan strategi. ${ }^{13}$ Politik merupakan sebuah bentuk tindakan dan pertimbangan manusia yang multidimensi. ${ }^{14}$

Pertimbangan politik (the nature of politics) meliputi 4 tipe reason: (a) Idiographic menunjuk pada "siapa saya" dan berkaitan dengan identitas. (b) Purposive menunjuk pada "apa yg kuinginkan" berkaitan dengan proses pembentukan kepentingan/preferences. (c) Ethical menunjuk bagaimana "saya harus bertindak" ada norma sosial. (d) Instrumental menunjuk bagaimana "saya bisa mendapat apa yang saya inginkan" berkaitan dengan metode atau cara. Hal penting yang bisa ditarik adalah bahwa tindakan politik aktor dipengaruhi oleh pertimbangan empat tipe reason tersebut.

Contoh dari hal ini adalah tindakan NATO mengebom Serbia dapat dijelaskan sebagai tindakan yang dilakukan setelah mempertimbangkan 4 hal di atas. Dalam merasionalkan dan menjustifikasi tindakannya, anggota NATO menyatakan bahwa identitas mereka sebagai kelompok yang didirikan di atas prinsip-prinsip atau norma-norma demokrasi, kebebasan individu dan rule of law, mengarahkan tujuan atau kepentingan mereka dalam mengatasi tantangan krisis di Kosovo, dan tindakan militer NATO merupakan cara yang tepat untuk mencapai tujuan atau kepentingan tadi. Politik memiliki bentuk yang khusus dari reason karena kualitas interstitialnya (lihat gambar 1).

\footnotetext{
${ }^{12}$ Reus Smit, Christian.The Politics of International Law (Cambridge: Cambridge University Press, 2004), h. 22.

13 Risse, Thomas, Lets Argue: Communicative Action in World politics, (International Organization 54: 1, Winter, 2000), h. 3-4.

${ }^{14}$ Reus Smit, Christian, The Politics of International Law (Cambridge: Cambridge University Press, 2004), h. 24.
} 


\section{Atep Abdurofiq}

Idiographic

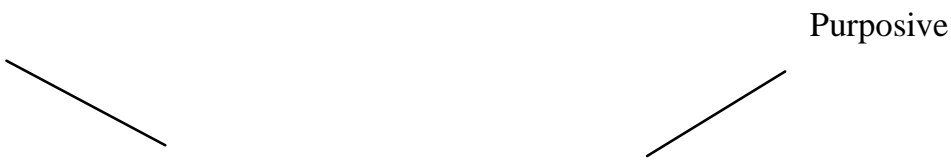

POLITICS

Ethical

Gambar 1 The Interstitial conception of politics

(Sumber: Christian Reus Smit, The Politics of International Law

(Cambridge: Cambridge University Press, 2004) p. 26

Carr memberikan terminologi yang berbeda, ide politik ditangkap dalam kritik Carr meskipun mengabaikan pengamatan bahwa politik tidak bisa dipisahkan dari power (kekuasaan). Tetapi konsep homo politicus di mana aktor hanya melakukan usaha untuk mendapatkan kekuasaan merupakan mitos yang tidak nyata seperti konsep homo economicus dimana aktor hanya melakukan usaha untuk mendapatkan keuntungan. Menurut Carr aksi politik harus didasarkan pada koordinasi antara moralitas dan power (kekuasaan). ${ }^{15}$

Jika pertimbangan politik merupakan hal yang multi-dimensional. Hal itu berlaku juga pada political action. Karena political action merupakan ekspresi perilaku dari political reason, masing-masing aspek dari alasan tersebut mempengaruhi ekspresi politik praktis. Alasan idiographic berada dibalik perilaku aktor dalam rangka melakukan artikulasi, justifikasi, menunjukkan, menyelenggarakan, dan memperdebatkan identitas aktor dengan melalui komunikasi verbal dan proses ritual.

\section{Latar Belakang Terbentuknya Konvensi PBB Anti Korupsi}

Memasuki abad 21 ini, salah satu visi masyarakat internasional adalah semakin kuatnya kesepakatan untuk saling bekerjasama dalam pemberantasan

${ }^{15}$ Carr, Twenty Years Crisis, hal. 97 dalam Christian Reus Smit, The Politics of International Law (Cambridge: Cambridge University Press, 2004), h. 24 
praktek-praktek korupsi. Hal ini dibuktikan dengan ditandatanganinya deklarasi untuk memberantas korupsi dalam KAK 2003 (United Nations Convention AgaintsCorruption/ UNCAC) yang diadakan oleh PBB. KAK 2003 ini digelar karena korupsi telah menggoyahkan sendi-sendi kehidupan sosial dan ekonomi masyarakat di suatu negara dan memberikan implikasi pula terhadap masyarakat internasional. Selain itu, korupsi berpotensi mengganggu stabilitas dan keamanan masyarakat serta dapat memperlemah nilai-nilai demokrasi, etika, keadilan, dan kepastian hukum. Melemahnya nilai-nilai ini, akan dapat membahayakan kelangsungan dan keberlanjutan pembangunan (jeopardizing sustainable development). Dalam praktiknya, korupsi dapat menjadi mata rantai kejahatan yang terorganisasi (crimeorganized), pencucian uang (money laundering), dan kejahatan ekonomi (economic crime) lainnya. Bentuk-bentuk kejahatan besar yang muncul sebagai akibat dari korupsi ini dapat merusak prinsip-prinsip persaingan sehat (fair competition) dan menyuburkan persaingan tidak sehat (unfair competition) di dunia bisnis. ${ }^{16}$

Sebelum UNCAC terbentuk, ada beberapa Konvensi Anti Korupsi tingkat internasional yaitu: ${ }^{17}$

1. 1977: The United States Congress oleh Perusahaan-perusahaan yang ada di Amerika Serikat. Kongres ini mengangkat masalah praktek korupsi berupa kriminalisasi suap oleh pejabat asing.

2. 1980: Cold War Security mempromosikan konvensi anti korupsi tingkat internasional.

3. 1996: The Inter-American Convention Against Corruption yang merupakan Konvensi Anti Korupsi Tingkat regional pertama kali.

4. 1997: The OECD Convention dalam memberantas Suap oleh pejabat asing (Bribery of Foreign Public Officials).

5. 1998-1999: The Council of Europe yang menghasilkan 2 kesepakatan anti korupsi yaitu: Hukum Kriminal (Criminal Law); Konvensi Hukum Sipil (Civil Law Convention).

6. 2000: The UN Convention dalam memberantas Transnational Organized Crime.

\footnotetext{
${ }^{16}$ http://www.pikiran-rakyat.com/cetak/2005/0105/15/0801.htmdiakses pada tanggal 4 September 2016 pukul 12:28.

${ }^{17 h t t p: / / a c c h . k p k . g o . i d / d o c u m e n t s / 10180 / 15914 / G A P+A n a l y s i s+I n d o n e s i a+t e r h a d a p+U N C ~}$ AC.pdf/46ac7384-bace-4052-9172-75723ed202b8. Diakses pada tanggal 4 September 2016 pukul 12:28.
} 


\section{Atep Abdurofiq}

7. 2003: The African Union Convention yang membahas masalah pencegahan dan pemberantasan korupsi.

UNCAC (United Nations Convention Againts Corruption) adalah konvensi anti korupsi pertama tingkat global yang mengambil pendekatan komprehensif dalam menyelesaikan masalah korupsi. UNCAC terdiri dari delapan bab dengan 71 pasal yang mengharuskan negara-negara peratifikasi mengimplementasikan isi dari konvensi tersebut.

Adapun tujuan umum dari KAK 2003 adalah:18 (1) Memajukan dan mengambil langkah-langkah tegas dalam pencegahan dan pemberantasan korupsi secara efektif dan efisien (to promote and strenghthen measures to prevent and combat corruption more efficiently and effectively). (2) Memajukan, memfasilitasi, dan mendukung kerjasama internasional dan bantuan teknik dalam mencegah dan memerangi perbuatan korupsi, termasuk pengembalian aset (to promote, facilitate and support international cooperation and technical assistance in the prevention of and fight against corruption, including in asset recovery). (3) Memajukan integritas, pertanggungjawaban, dan hubungan manajemen publik yang sesuai dengan kepemilikan umum (to promote integrity, accountability and proper management of public affairs and public property).

Lingkup Konvensi pembukaan dan batang tubuh yang terdiri atas 8 (delapan) bab dan 71 (tujuh puluh satu) pasal dengan sistematika sebagai berikut: 19

Bab I: Ketentuan Umum, memuat Pernyataan Tujuan; Penggunaan Istilah-istilah; Ruang lingkup Pemberlakuan; dan Perlindungan Kedaulatan.

Bab II: Tindakan-tindakan Pencegahan, memuat Kebijakan dan Praktek Pencegahan Korupsi; Badan atau Badan-badan Pencegahan Korupsi; Sektor Publik; Aturan Perilaku Bagi Pejabat Publik; Pengadaan Umum dan Pengelolaan Keuangan Publik; Pelaporan Publik; Tindakan-tindakan yang Berhubungan dengan Jasa-jasa Peradilan dan Penuntutan; Sektor Swasta; Partisipasi Masyarakat; dan Tindakan-tindakan untuk Mencegah Pencucian Uang.

Bab III: Kriminalitas dan Penegakan Hukum, memuat Penyuapan Pejabat-pejabat Publik Nasional, Penyuapan Pejabat-pejabat Publik Asing dan

\footnotetext{
${ }^{18}$ http://acch.kpk.go.id/documents/10180/15914/GAP+Analysis+Indonesia+terhadap+UNC AC.pdf/46ac7384-bace-4052-9172-75723ed202b8

${ }^{19}$ http://www.unsrat.ac.id/hukum/uu/uu 7 06.htmdiakses pada tanggal 4 September 2016 pukul 12:28.
} 
Pejabat-pejabat Organisasi-Organisasi Internasional Publik; Penggelapan, Penyalahgunaan atau Penyimpangan lain Kekayaan oleh Pejabat Publik; Memperdagangkan Pengaruh; Penyalahgunaan Fungsi; Memperkaya Diri Secara Tidak Sah; Penyuapan di Sektor Swasta; Penggelapan Kekayaan di Sektor Swasta; Pencucian Hasil-Hasil Kejahatan; Penyembunyian; Penghalangan Jalannya Proses Pengadilan; Tanggung Jawab Badan-badan Hukum; Keikutsertaan dan Percobaan; Pengetahuan, Maksud dan Tujuan Sebagai Unsur Kejahatan; Aturan Pembatasan; Penuntutan dan Pengadilan, dan Saksi-saksi; Pembekuan, Penyitaan dan Perampasan; Perlindungan para Saksi, Ahli dan Korban; Perlindungan bagi Orang-orang yang Melaporkan; Akibat-akibat Tindakan Korupsi; Kompensasi atas Kerugian; Badan-badan Berwenang Khusus; Kerja Sama dengan Badan-badan Penegak Hukum; Kerja Sama antar Badan-badan Berwenang Nasional; Kerja Sama antara Badan-badan Berwenang Nasional dan Sektor Swasta; Kerahasian Bank; Catatan Kejahatan; dan Yurisdiksi.

Bab IV: Kerja Sama Internasional. memuat Ekstradisi; Transfer Narapidana; Bantuan Hukum Timbal Balik; Transfer Proses Pidana; Kerja Sama Penegakan Hukum; Penyidikan Bersama; dan Teknik-teknik Penyidikan Khusus.

Bab V: Pengembalian Aset, memuat Pencegahan dan Deteksi Transfer Hasil-hasil Kejahatan; Tindakan-tindakan untuk Pengembalian Langsung atas Kekayaan; Mekanisme untuk Pengembalian Kekayaan melalui Kerja Sama Internasional dalam Perampasan; Kerja Sama Internasional untuk Tujuan Perampasan; Kerja Sama Khusus; Pengembalian dan Penyerahan Aset; Unit Intelijen Keuangan; dan Perjanjian-perjanjian dan Pengaturan-pengaturan Bilateral dan Multilateral.

Bab VI :Bantuan Teknis dan Pertukaran Informasi, memuat Pelatihan dan Bantuan Teknis; Pengumpulan, Pertukaran, dan Analisis Informasi tentang Korupsi; dan Tindakan-tindakan lain; Pelaksanaan Konvensi melalui Pembangunan Ekonomi dan Bantuan Teknis.

Bab VII: Mekanisme-mekanisme Pelaksanaan, memuat Konferensi Negara-negara Pihak pada Konvensi; dan Sekretariat.

Bab VIII: Ketentuan-ketentuan Akhir, memuat Pelaksanaan Konvensi; Penyelesaian Sengketa; Penandatanganan, Pengesahan, Penerimaan, Persetujuan, dan Aksesi; Pemberlakuan; Amandemen; Penarikan Diri; Penyimpanan dan Bahasa-bahasa. 


\section{Atep Abdurofiq}

\section{Tahap-Tahap Pembuatan UNCAC}

Proses pembuatan UNCAC (United Nations Convention Againts Corruption) dilakukan melalui beberapa tahap yaitu: Perundingan (Negotiation), Penandatanganan (Signature), dan Ratifikasi (Ratification). Pelaksanaan dari tahapan-tahapan tersebut membutuhkan waktu yang tidak singkat, sehingga akhirnya sampai pada penyelesaian akhir dari konvensi tersebut.

Pertama, Perundingan (Negotiation). Penyusunan Konvensi Perserikatan Bangsa-Bangsa diawali sejak tahun 2000 di mana Majelis Umum Perserikatan Bangsa-Bangsa dalam sidangnya ke-55, melalui Resolusi Nomor 55/61 pada tanggal 6 Desember 2000, memandang perlu dirumuskannya instrumen hukum internasional antikorupsi secara global. Instrumen hukum internasional tersebut amat diperlukan untuk menjembatani sistem hukum yang berbeda dan sekaligus memajukan upaya pemberantasan tindak pidana korupsi secara efektif. Untuk tujuan tersebut, Majelis Umum Perserikatan Bangsa-Bangsa membentuk Ad Hoc Committee (Komite Ad Hoc) yang bertugas merundingkan draft Konvensi. ${ }^{20}$ Komite Ad Hoc yang beranggotakan mayoritas negara-negara anggota Perserikatan Bangsa-Bangsa memerlukan waktu hampir 2 (dua) tahun untuk menyelesaikan pembahasan sebelum akhirnya menyepakati naskah akhir Konvensi untuk disampaikan dan diterima sidang Majelis Umum Perserikatan Bangsa-Bangsa

Kedua, Penandatanganan (Signature). United Nations Convention Againts Corruption diterima oleh Majelis Umum PBB pada tanggal 31 Oktober 2003 di Markas Besar PBB di New York Amerika Serikat. Proses penandatanganan konvensi tersebut diadakan pada tanggal 9 sampai dengan 11 Desember 2003 di Merida Meksiko. Jumlah negara yang telah membubuhkan tanda tangan adalah 111 negara. Kemudian proses penandatanganan dilanjutkan sampai tanggal 19 September 2005 di Markas Besar PBB dan pada saat itu telah ada 140 negara yang menandatangani konvensi tersebut. Proses penandatanganan ini sesuai dengan Pasal 67 Ayat 1 UNCAC. ${ }^{21}$

Ketiga, Ratifikasi (Ratification). Kekuatan mengikat United Nations Convention Againts Corruption baru terjadi pada tanggal 15 September 2005

${ }^{20}$ http://www.unsrat.ac.id/hukum/uu/uu_7_06.htmpada tanggal 4 September 2016 pukul $12: 28$.

21 This Convention shall be open to all States for signature from 9 to 11 December 2003 in Merida, Mexico, and thereafter at United Nations Headquarters in New York until 9 December 2005. 
setelah 30 negara yang telah membubuhkan tanda tangan meratifikasi isi dari konvensi tersebut. Sampai dengan tahun 2007 ada 129 negara yang telah meratifikasi konvensi tersebut. Adapun daftar negara-negara yang menandatangani dan meratifikasi adalah sebagaimana terlampir. ${ }^{22}$

\section{Conference of State Parties (CoSP)}

Conference of State Parties merupakan pertemuan negara-negara pihak UNCAC yang pertama kali atau lebih dikenal dengan The First Conference of State Parties (CoSP I) sebagai tindak lanjut dari KAK 2003. Pertemuan ini diadakan pada tanggal 10-14 Desember 2006 di Yordania. Adapun hasil dari pertemuan tersebut adalah: (1) Perlu adanya mekanisme monitoring dalam rangka mengawasi implementasi UNCAC di negara-negara pihak yang telah meratifikasi UNCAC. (2) PBB akan mempromosikan koordinasi aktivitas yang berhubungan dengan bantuan teknis dan asset recovery. (3) Setiap negara pihak UNCAC perlu menindaklanjuti apabila terjadi permintaan suap secara sengaja atau penerimaan keuntungan illegal oleh pihak asing. (4) Negara-negara pihak UNCAC sepakat melaksanakan The Second Conferenceof State Parties (CoSP II) di Indonesia pada tanggal 28 Januari- 1 Pebruari2008.

\section{Konstruktivis Politik Hukum Ratifikasi Konvensi PBB Anti Korupsi}

Tekad memberantas korupsi di Indonesia mau tidak mau harus sepenuhnya didukung oleh penegakan hukum yang kuat dan professional. Performance dan kinerja penegakan hukum mutlak diberdayakan dan terberdayakan. Jika tidak, maka bisa jadi di era reformasi ini hanya akan terjadi pengulangan kegagalan memberantas korupsi pada masa sebelumnya. Dan semakin membuat bangsa-negara ini semakin terbenam dalam lumpur ketidakpastian.

Untuk mencegah itu maka Pemerintah Republik Indonesia pada tanggal 18 Desember 2003 di Markas Besar Perserikatan Bangsa-Bangsa telah ikut menandatangani Konvensi Perserikatan Bangsa-Bangsa tentang Anti Korupsi yang diadopsi oleh Sidang ke-58 Majelis Umum melalui Resolusi Nomor 58/4 pada tanggal 31 Oktober 2003 dan disahkan menjadi UU Nomor 7 Tahun 2006 tentang pengesahan United Nations Convention Against Corruption,

\footnotetext{
${ }^{22}$ http://www.unodc.org/unodc/crime convention corruption.htmldiakses pada tanggal 4 September 2016 pukul 12:54
} 


\section{Atep Abdurofiq}

2003 (konvensi perserikatan bangsa-bangsa anti korupsi, 2003) pada tanggal 18 April 2006 oleh Presiden Susilo Bambang Yudhoyono.

Konvensi ini sudah diratifikasi 47 negara dan Indonesia menjadi negara ke-48 yang turut meratifikasinya. Istilah ratifikasi sendiri berasal dari bahasa latin yaitu "ratificare" yang terbentuk dari kata ratus yang berarti dibuat atau dibentuk (made). Jadi ratifikasi secara harfiah dapat dikatakan dibuat mantap atau disahkan melalui persetujuan (make valid by approving). ${ }^{23}$ Indonesia memandang konvensi internasional tersebut cukup penting dalam upaya untuk menegakkan "good governance" transparansi dan akuntabilitas serta menciptakan iklim investasi yang kondusif. Konvensi itu mengatur mengenai kerjasama internasional untuk mengejar dan menangkap pelaku korupsi, menelusuri harta kejahatannya dan merepatriasi hasil-hasil korupsi mereka.

Konvensi ini cukup strategis jika dilihat dari sisi hukum internasional sebagai instrumen politik (realisme) karena dalam situasi tidak ada perjanjian ekstradisi bilateral, kita tetap bisa menggunakan perangkat ini untuk melakukan pemberantasan korupsi, seperti dapat dilihat dalam penjelasan UU Nomor 7 Tahun 2006 tentang pengesahan United Nations Convention Against Corruption, 2003 (konvensi perserikatan bangsa-bangsa anti korupsi, 2003) mengenai arti penting ratifikasi korupsi, sebagai berikut: (1) untuk meningkatkan kerja sama internasional khususnya dalam melacak, membekukan, menyita, dan mengembalikan aset-aset hasil tindak pidana korupsi yang ditempatkan di luar negeri; (2) meningkatkan kerja sama internasional dalam mewujudkan tata pemerintahan yang baik; (3) meningkatkan kerja sama internasional dalam pelaksanaan perjanjian ekstradisi, bantuan hukum timbal balik, penyerahan narapidana, pengalihan proses pidana, dan kerja sama penegakan hukum; (4) mendorong terjalinnya kerjasama teknik dan pertukaran informasi dalam pencegahan dan pemberantasan tindak pidana korupsi di bawah payung kerja sama pembangunan ekonomi dan bantuan teknis pada lingkup bilateral, regional, dan multilateral; dan (5) harmonisasi peraturan perundang-undangan nasional dalam pencegahan dan pemberantasan tindak pidana korupsi sesuai dengan Konvensi ini.

Arti penting di atas senada dengan apa yang telah diungkapkan oleh Hikmahanto Juwono bahwa eksistensi hukum internasional yang berfungsi

23 Priyatna Abdurrasyid, "Instrumen Hukum Nasional bagi Peratifikasian Perjanjian Internasional" dalam Majalah Hukum Nasional BPHN, No. 1 Tahun 1991, (Jakarta: BPHN, 1991), h. 29. 
sebagai instrumen politik didasarkan pada realitas hubungan antar negara. Hubungan antar negara tidak lepas dari kepentingan yang saling bersinggungan. Terlebih lagi di era global di mana batas fisik seolah tidak ada (borderless). Suatu negara akan menggunakan berbagai instrumen politik, seperti ketergantungan ekonomi, ketergantungan dalam masalah pertahanan, dan hukum internasional untuk mengenyampingkan halangan kedaulatan negara lain dalam mencapai kepentingan nasionalnya.

Di samping itu, hukum internasional menjadi instrumen politik bertolak pada keinginan negara demi kepentingan nasionalnya untuk turut campur dalam urusan domestik negara lain tanpa dianggap sebagai pelanggaran. Cara yang paling efektif untuk melakukan intervensi adalah dengan memanfaatkan perjanjian internasional sebagai salah satu produk hukum internasional. Perjanjian internasional dibuat sedemikian rupa, sehingga berimplikasi pada kewajiban bagi negara peserta untuk mentransformasikan ketentuan yang ada dalam perjanjian internasional ke dalam hukum nasionalnya. Dengan demikian hukum nasional suatu negara harus mencerminkan, bahkan tidak boleh bertentangan dengan, perjanjian internasional yang telah diikuti. ${ }^{24}$

Dalam pandangan Neoliberal Institusional di mana politik adalah sebuah permainan strategis di mana negara-negara yang egois akan berusaha memaksimalkan kepentingan masing-masing dalam menghadapi kendalakendala yang ada. Hukum internasional dilihat sebagai serangkaian aturanaturan fungsional yang dibuat untuk menyelesaikan persoalan-persoalan suatu kerjasama dalam situasi yang anarkis. ${ }^{25}$ Kepentingan Indonesia dalam meratifikasi konvensi anti korupsi adalah untuk mewujudkan masyarakat adil dan makmur berdasarkan Pancasila dan Undang-Undang Dasar Negara Republik Indonesia Tahun 1945, maka pemerintah bersama-sama masyarakat mengambil langkah-Iangkah pencegahan dan pemberantasan tindak pidana korupsi secara sistematis dan berkesinambungan.

Kendala yang dihadapi oleh Indonesia adalah bahwa tindak pidana korupsi tidak lagi merupakan masalah lokal, akan tetapi merupakan fenomena transnasional yang mempengaruhi seluruh masyarakat dan perekonomian sehingga penting adanya kerja sama internasional untuk pencegahan dan pemberantasannya termasuk pemulihan atau pengembalian aset-aset hasil

${ }^{24}$ Hukum Internasional sebagai Instrumen Politik, Hikmahanto Juwana (2013), Guru Besar Hukum Internasional pada Fakultas Hukum Universitas Indonesia.

25 Christian Reus-Smit, The Moral Purpose of The State: Culture, Social Identity, and Institutional Rationality in International Relations (Princeton University Press, 1999). 


\section{Atep Abdurofiq}

tindak pidana korupsi. Kerja sama internasional diperlukan untuk menyelesaikan masalah korupsi ini dalam rangka pencegahan dan pemberantasan tindak pidana korupsi, tentunya perlu didukung oleh integritas, akuntabilitas, dan manajemen pemerintahan yang baik dan bangsa Indonesia telah ikut aktif dalam upaya masyarakat internasional untuk pencegahan dan pemberantasan tindak pidana korupsi dengan telah menandatangani United Nations Convention Against Corruption, 2003 (Konvensi Perserikatan Bangsa-Bangsa Anti Korupsi, 2003).

Dari segi konstruktivisme ratifikasi konvensi anti korupsi ini dapat dilihat sebagai upaya mengkonstruksi identitas Indonesia yang mulanya sebagai negara yang korup menjadi negara yang mempunyai keinginan untuk menciptakan pemerintahan yang bersih, seperti tertuang dalam penjelasan UU Nomor 7 Tahun 2006 tentang pengesahan United Nations Convention Against Corruption, 2003 (konvensi perserikatan bangsa-bangsa anti korupsi, 2003) mengenai arti penting ratifikasi korupsi, sebagai berikut : "Ratifikasi Konvensi ini merupakan komitmen nasional untuk meningkatkan citra bangsa Indonesia dalam percaturan politik internasional."

Jika ditilik konsep konstruktivisme dimana aktor (Indonesia) tidak hanya bertindak untuk merespon lingkungan material mereka; maka aktor juga memiliki keyakinan-keyakinan intersubyektif, keyakinan yang dimiliki Indonesia adalah bahwa Indonesia meyakini bahwa korupsi merupakan sebuah penyakit yang buruk dan perlu dihilangkan, keyakinan ini kemudian membentuk identitas aktor (Indonesia) sebagai negara yang tengah melakukan reformasi dan berupaya melakukan perubahan dari negara yang korup menjadi negara yang bersih, dan pada gilirannya hal tersebut membentuk kepentingan Indonesia untuk meningkatkan atau membentuk citra yang baik dalam kancah politik internasional. Jika ingin memahami perilaku aktor, maka perlu memahami identitas sosial mereka, dimana identitas itulah yang mengkondisikan dan membentuk kepentingan dan tindakan aktor tersebut. Manusia selalu berinteraksi, interaksinya ini akan membentuk keyakinannya dan keyakinan tersebut akan membentuk identitas, identitas kemudian mempengaruhi kepentingan dan kepentingan akan mempengaruhi tindakannya. Karena manusia selalu berinteraksi, maka ia bukanlah mahluk yang statis, tapi dimanis, sehingga bisa melakukan perubahan (transformasi).

Salah satu inti dari konstruktivisme adalah Reason for Action. Reason di sini meliputi motif kolektif maupun individual jika dikaitkan dengan Indonesia maka Reason di sini adalah alasan mengapa Indonesia meratifikasi Konvensi PBB Anti Korupsi. Selain motif kolektif dan individual ada satu hal lagi yang 
menjadi bagian dari Reason for Action yaitu klaim justifikasi (justifikasi Indonesia meratifikasi Konvensi PBB Anti Korupsi). Reason punya dua dimensi, yaitu dimensi internal dan eksternal atau private-public. Struktur normatif dan ideational membentuk reason aktor dalam dua dimensi yaitu: (1) Melalui proses sosialisasi, dengan sosialisasi tersebut struktur tersebut membentuk definisi aktor mengenai siapa dia dan apa yang dia inginkan.

Dalam hal ini Indonesia mengidentifikasikan dirinya sebagai negara yang mempunyai tingkat korupsi yang tinggi. Peringkat indeks persepsi korupsi atau corruption perception index (CPI) Indonesia naik dua poin pada 2015 dibanding 2014. Untuk penilaian tahun 2015, Indonesia meraih skor 36, naik dibanding tahun sebe-lumnya 34. Skor CPI berada pada rentang 0 hingga 100. Negara dengan skor 0 berarti negara itu dipersepsikan sangat korup. Sebaliknya, negara yang memiliki skor 100, berarti dipersepsikan sangat bersih. Penilaian lembaga nirlaba Transparency International ini menjadi indikator terkemuda praktik korupsi di suatu negara. Penilaian ini diberikan oleh para pebisnis dan para pakar terhadap praktik korupsi sektor publik atau dilakukan aparatur negara. Kenaikan indeks tahun 2015 mendongkrat peringkat Indonesia ke posisi 15 untuk regional. Sedangkan untuk tingkat dunia, Indonesia berada pada urutan 88 dari 168 negara yang dinilai. Pada tahun 2014, Indonesia menempati peringkat 107. Kendati mengalami peningkatan skor 2 poin, hal itu belum cukup menandingi skor dan peringkat yang diraih negaranegara di kawasan. ${ }^{26}$

Berdasarkan data-data itu, Indonesia ingin mengurangi serta membasmi praktik-praktik korupsi. Adanya norma-norma dan ide-ide yang berlaku di dunia ini seperti demokrasi, transparansi dan akuntabilitas membentuk identitas Indonesia dan pada akhirnya membentuk dan mempengaruhi keputusan Indonesia untuk meratifikasi konvensi PBB anti korupsi. (2) Melalui proses justifikasi publik, dengan justifikasi tersebut struktur tadi memberi kerangka bagi logic of argument. Sedangkan justifikasi bagi Indonesia untuk melakukan ratifikasi konvensi PBB anti korupsi adalah gagalnya upaya pemberantasan korupsi serta penyelenggaraan pemerintahan yang korup telah mendorong tingginya inefisiensi di hampir seluruh level pemerintahan di Indonesia.

Kecenderungan politik Indonesia dalam meratifikasi konvensi PBB bisa tergambar sebagai berikut: (1) Idiographic menunjuk pada "siapa saya" dan

${ }^{26}$ http://www.rmol.co/read/2016/02/01/234187/Meski-Indeks-Persepsi-Membaik,-Indonesia-Masih-Darurat-Korupsi- diakses 30 September 2016 Pukul 5.50 WIB. 


\section{Atep Abdurofiq}

berkaitan dengan identitas, dalam hal ini Indonesia mengidentitaskan dirinya sebagai negara yang mempunyai tingkat korupsi yang tinggi. (2) Purposive menunjuk pada "apa yang kuinginkan" berkaitan dengan proses pembentukan kepentingan/preferences, dalam konteks ini Indonesia menginginkan adanya usaha untuk meningkatkan citra bangsa Indonesia dalam percaturan politik internasional, sebagai negara yang memiliki pemerintahan yang bersih, adil dan demokratis serta untuk meningkatkan kerja sama internasional khususnya dalam melacak, membekukan, menyita, dan mengembalikan aset-aset hasil tindak pidana korupsi yang ditempatkan di luar negeri dan juga meningkatkan kerja sama internasional dalam mewujudkan tata pemerintahan yang baik; meningkatkan kerja sama internasional dalam pelaksanaan perjanjian ekstradisi, bantuan hukum timbal balik, penyerahan narapidana, pengalihan proses pidana, dan kerja sama penegakan hukum; mendorong terjalinnya kerja sama teknik dan pertukaran informasi dalam pencegahan dan pemberantasan tindak pidana korupsi di bawah payung kerja sama pembangunan ekonomi dan bantuan teknis pada lingkup bilateral, regional, dan multilateral; dan harmonisasi peraturan perundang-undangan nasional dalam pencegahan dan pemberantasan tindak pidana korupsi sesuai dengan Konvensi ini. (3) Ethical menunjuk bagaimana "saya harus bertindak" ada norma sosial, dalam hal ini dengan adanya norma-norma dan ide-ide yang berlaku di dunia ini seperti demokrasi, transparansi dan akuntabilitas membentuk pola bagaimana seharusnya Indonesia bertindak dan pada akhirnya membentuk dan mempengaruhi keputusan Indonesia untuk meratifikasi konvensi PBB anti korupsi. (4) Instrumental menunjuk bagaimana "saya bisa mendapat apa yang saya inginkan" berkaitan dengan metode atau cara. Hal penting yang bisa ditarik adalah bahwa tindakan politik aktor dipengaruhi oleh pertimbangan empat tipe reason tersebut. Dalam hal ini Indonesia untuk mendapat apa yang diinginkan dengan melakukan ratifikasi konvensi PBB anti korupsi.

Tindak pidana korupsi merupakan ancaman terhadap prinsip-prinsip demokrasi, yang menjunjung tinggi transparansi, akuntabilitas, dan integritas, serta keamanan dan stabilitas bangsa Indonesia. Oleh karena korupsi merupakan tindak pidana yang bersifat sistematik dan merugikan pembangunan berkelanjutan, sehingga memerlukan langkah-langkah pencegahan dan pemberantasan yang bersifat menyeluruh, sistematis, dan berkesinambungan baik pada tingkat nasional maupun tingkat internasional.

Dalam melaksanakan pencegahan dan pemberantasan tindak pidana korupsi yang efisien dan efektif diperlukan dukungan manajemen tata pemerintahan yang baik dan kerjasama internasional, termasuk pengembalian 
aset-aset yang berasal dari tindak pidana korupsi. Selama ini pencegahan dan pemberantasan tindak pidana korupsi di Indonesia sudah dilaksanakan berdasarkan peraturan perundang-undangan khusus yang berlaku sejak tahun 1957 dan telah diubah sebanyak 5 (lima) kali, akan tetapi peraturan perundangundangan dimaksud belum memadai, antara lain karena belum adanya kerja sama internasional dalam masalah pengembalian hasil tindak pidana korupsi. Pemerintah Republik Indonesia pada tanggal 18 Desember 2003 di Markas Besar Perserikatan Bangsa-Bangsa telah ikut menandatangani Konvensi Perserikatan Bangsa-Bangsa tentang Anti Korupsi yang diadopsi oleh Sidang ke-58 Majelis Umum melalui Resolusi Nomor 58/4 pada tanggal 31 Oktober 2003.

\section{Penutup}

Berdasarkan uraian-uraian terdahulu, maka pada akhirnya studi ini mempunyai kesimpulan bahwa Indonesia memandang konvensi PBB anti korupsi cukup penting dalam upaya menegakkan "good governance" dan menciptakan iklim investasi yang kondusif. Konvensi itu mengatur mengenai kerjasama internasional untuk mengejar dan menangkap pelaku korupsi, menelusuri harta kejahatannya dan merepatriasi hasil-hasil korupsi mereka. Konvensi ini cukup strategis jika dilihat dari sisi hukum internasional sebagai instrumen politik (realisme) karena dalam situasi tidak ada perjanjian ekstradisi bilateral, kita tetap bisa menggunakan perangkat ini untuk melakukan pemberantasan korupsi.

Hal lain yang dapat dilihat dari perspektif neoliberal institusional adalah bahwa kerjasama internasional diperlukan untuk menyelesaikan masalah korupsi ini dalam rangka pencegahan dan pemberantasan tindak pidana korupsi, tentunya perlu didukung oleh integritas, akuntabilitas, dan manajemen pemerintahan yang baik dan bangsa Indonesia telah ikut aktif dalam upaya masyarakat internasional untuk pencegahan dan pemberantasan tindak pidana korupsi dengan telah menandatangani United Nations Convention Against Corruption, 2003 (Konvensi Perserikatan Bangsa-Bangsa Anti Korupsi, 2003). Dari perspektif konstruktivisme ratifikasi adalah sebagai upaya mengkonstruksi identitas Indonesia yang mulanya sebagai negara yang korup menjadi negara yang mempunyai keinginan untuk menciptakan pemerintahan yang bersih.

\section{Pustaka Acuan}




\section{Atep Abdurofiq}

\section{BUKU}

Abdurrasyid, Priyatna, "Instrumen Hukum Nasional bagi Peratifikasian Perjanjian Internasional" dalam Majalah Hukum Nasional BPHN, No. 1 Tahun 1991, BPHN, Jakarta.

Adler, E, Seizing the middle ground: constructivism in world politics. European Journal of International Relations, 3 (3), 1997.

Juwana, H, Hukum Internasional Sebagai Instrumen Politik: Beberapa Pengalaman Indonesia Sebagai Studi Kasus. Arena Hukum, 5(2), 2013.

Kian Gie, Kwik, Pemberantasan Korupsi Untuk Meraih Kemandirian, Kesejahteraan, Kemakmuran dan Keadilan. Jakarta: tanpa penerbit, 2003.

Klitgaard, R, Controlling corruption. California: University of California Press, 1988.

Klotz, Audie, Norms in International Relations: The Struggle Against Apartheid. Ithaca: Cornell University Press, 1995.

Kratochwill, Friedrich V, Rules, Norms, and Decisions: On the Condition of Practical and Legal Reasoning in International Relations and Domestic Affairs Cambridge: Cambridge University Press, 1989.

Kusumaatmadja, Mochtar, Pengantar Hukum Internasional, Buku I Bagian Umum. Bandung: Bina Cipta, 1981.

Reus-Smith, Christian, Constructivism dalam Scot Burchill, Richard Devetak, (et all). Theories of International Relations, Second Edition. New York: Palgrave, 2001.

Reus Smit, Christian, The Politics of International Law. Cambridge: Cambridge University Press, 2004.

Risse, T, "Let's argue!": Communicative Action in World Politics. International organization, 54(01), 2000.

Wendt, Alexander, Social Theory of International Politics. Cambridge: Cambridge University Press, 1999.

Wendt, Alexander, The Agent Structure Problem in International Relations Theory, International Organization, 1987.

\section{WEBSITE}

http://www.bakun.go.id

http://www.pikiran-rakyat.com

http://acch.kpk.go.id

http://www.unsrat.ac.id

http://www.unodc.org

http://www.rmol.co 